\title{
Aplikasi Sistem Pakar Mendiagnosa Gizi Buruk Pada Anak Dengan Metode Dempster- Shafer Berbasis Web
}

\author{
Mustamin Hamid ${ }^{1}$, Adelina Ibrahim ${ }^{2}$, Fadril M Lausi ${ }^{3}$ \\ Program Studi Teknik Informatika \\ Fakultas Teknik, Universitas Muhammadiyah Maluku Utara \\ hamidmustamin@gmail.com
}

\begin{abstract}
Abstrak
Sistem pakar adalah sistem berbasis komputer yang menggunakan pengetahuan, fakta, dan teknik penalaran dalam memecahkan masalah yang biasanya hanya dapat dipecahkan oleh pakar bidang tertentu. Puskesmas Ome Kota Tidore Kepulauan Selama ini, untuk mendata gizi buruk pada anak-anak melakukannya secara manual. Sehingga membutuhkan waktu yang lama. Peniltian ini bertujuan merancang aplikasi sistem pakar untuk menentukan status gizi buruk pada anak dengan menggunakan metode dempster-shafer, dimana ada beberapa jenis gizi buruk yang biasa dialami oleh anak, karena itu dalam kasus ini ada 3 jenis gizi buruk yang dibahas, yaitu marasmus (kekurangan energi), khowarsiorkor (kekurangan protein), dan marasmus-khowarsiorkor (kekurangan protein dan energi), yang digunakan untuk mengkombinasikan potongan informasi yang terpisah (bukti) untuk mengkalkulasi kemungkinan dari suatu peristiwa. Dengan adanya penelitian ini diharapkan dapat memudahkan pihak puskesmas dalam mengelola dan melacak gizi buruk pada anak-anak di Puskesmas Ome Kota Tidore Kepulauan.
\end{abstract}

\section{Kata kunci : Sistem Pakar, Gizi Buruk, Dempster-Shafer, Website}

\begin{abstract}
Expert system is a computer-based system that uses knowledge facts, and reasoning in solving problems which usually can only be solved by an expert on a particular field, ome community health center of tidore island city, to register a malnutrition in children do it manually, So it takes a long time. This research aims to design an application expert system to determine the status of malnutrition in children using dempster-shafer, where there are several types of malnutrition that is commonly experienced by children, therefore in this case there are 3 types of malnutrition are discussed is marasmus (lack of energy), khowarsiorkor (protein deficiency), and marasmus-khowarsiorkor (lack of protein and energy), used to combine separate pieces of information (evidence) to calculate the probability of an event. The existence of this research are expected to make it easier for parties to seek in managing and keep track of malnutrition in children in Ome community health center of tidore island city
\end{abstract}

Keywords : Expert Sistem, Malnutrition, Dempster-Shafer, Website

\section{PENDAHULUAN}

Pada tahun 2012, Indonesia Negara kekurangan gizi nomor 5 di dunia. Peringkat kelima karena jumlah penduduk Indonesia juga di urutan empat terbesar dunia, jumlah balita yang kekurangan gizi di Indonesia saat ini sekitar 900 ribu jiwa. Jumlah tersebut merupakan 4,5 persen dari jumlah balita Indonesia, yakni 23 juta jiwa.
Daerah yang kekurangan gizi tersebar di seluruh Indonesia, tidak hanya daerah bagian timur Indonesia. Hingga hari ini Indonesia masih dihantui kasus gizi buruk.

Pola gizi seimbang sangat penting dalam masa pertumbuhan anak karena faktor pertumbuhan dan perkembangan serta kecerdasannya dipengaruhi oleh gizi terutama di Indonesia bagian Timur. 
Seringkali orang tua menganggap status gizi pada anaknya baik tanpa memeriksakan kepada ahli gizi, sehingga pada akhirnya anak mengalami gizi buruk dan keterlambatan penanganan. Gizi buruk dipengaruhi oleh banyak faktor yang saling terkait. Secara garis besar penyebab anak kekurangan gizi disebabkan karena asupan makanan yang kurang atau anak sering sakit/terkena infeksi. banyak orang tua yang memiliki pengetahuan terbatas masalah gizi. Gizi buruk harus segera ditangani, karena apabila terlambat melakukan tindakan penanganan dapat menyebabkan kematian, dalam hal ini, Gizi buruk masih merupakan masalah di Indonesia, walaupun Pemerintah Indonesia telah berupaya untuk menanggulanginya.

Status gizi dan deteksi gizi buruk pada anak secara dini merupakan hal yang penting dalam proses tumbuh kembang anak. Saat ini aplikasi tunggal teknik kecerdasan buatan (Artificial Intelligence) yang terbesar adalah Sistem Pakar (Expert System). Sistem pakar adalah sistem berbasis komputer yang menggunakan pengetahuan, fakta, dan teknik penalaran dalam memecahkan masalah yang biasanya hanya dapat dipecahkan oleh pakar bidang tertentu. Pengetahuan dan pengalaman yang akan direpresentasikan ke sistem pakar memiliki banyak unsur ketidakpastian. Selama ini, untuk mendata gizi buruk pada anak-anak pihak Puskesmas Ome Kota Tidore Kepulauan melakukannya secara manual. Sehingga membutuhkan waktu yang lama. Oleh karena itu, penulis memanfaatkan metode dempster-shafer dengan pemrograman berbasis Web untuk memudahkan pihak puskesmas dalam melacak kasus gizi buruk pada anak-anak di Puskesmas Ome Kota Tidore Kepulauan.

\section{Rumusan Masalah}

Bagaimana merancang Aplikasi Sistem Pakar diagnose Gizi Buruk Anak dengan mengunakan metode Dempster-Shafer Berbasis Web pada Puskesmas Ome Kota Tidore Kepulauan

\section{Tujuan Penilitian}

Merancang Aplikasi Sistem Pakar Mendiagnosa Gizi Buruk Pada Anak Dengan mengunakan metode DempsterShafer berbasis web pada Puskesmas Ome Kota Tidore Kepulauan

\section{Manfaat Penilitian}

Memudahkan pihak puskesmas dalam mengelola dan melacak gizi buruk pada anak-anak di Puskesmas Ome Kota Tidore Kepulauan.

\section{Tinjauan Pustaka}

Menurut Risky Ambarita dalam penelitian yang berjudul Sistem Pakar Diagnosa Kerusakan Mainboard Komputer mengatakan bahwa Mainboard Komputer adalah sebuah perangkat keras yang terdapat pada komputer dan tempat di mana semua perangkat keras yang lain dipasangkan. Oleh karena itu, kerusakan yang terdapat pada mainboard sangat berpengaruh pada seluruh kinerja komputer. Banyak berbagai permasalahan yang sering dikeluhkan oleh para pengguna komputer, terkadang mereka memerlukan teknisi atau pakar untuk medeteksi kerusakan tersebut. Sebagian dari pengguna komputer menganggap bahwa pekerjaan penelusuran kesalahan atau kerusakan pada komputer terlalu rumit untuk dilakukan sehingga memerlukan pakar atau teknisi dalam menangani masalah kerusakan pada mainboard tersebut. Penilitian ini menggunakan model pencarian kerusakan yaitu metode pelacakan kedepan (Forward 
chaining), bahasa pemograman yang digunakan adalah PHP dengan database MySql. Dengan adanya sistem ini diharapkan dapat memberikan kemudahan pada pengguna komputer untuk mengetahui gejala-gejala kerusakan yang terjadi pada Mainboard Komputer yang dapat diakses pada sistem dimana saja

Menurut Yasidah Nur Istiqomah, Abdul Fadlil pada judul penelitiannya Sistem Pakar untuk Mendiagnosa Penyakit Saluran Pencernaan Menggunakan Metode Dempster Shafer mengatakan bahwa Penyakit saluran pencernaan merupakan penyakit yang berbahaya dan menyebabkan kematian nomor 6 di dunia, dikarenakan pengetahuan akan gejala awal suatu penyakit yang kurang, kesadaran akan kesehatan masyarakat yang masih rendah, kebiasaan hidup, perilaku dan pola pikir dari masyarakat yang ingin hidup praktis, sarana media penyampaian informasi tentang penyakit yang masih kurang, serta minimnya jumlah tenaga medis merupakan masalah yang dihadapi dalam kasus ini, sehingga perlu adanya media bantu berupa sistem yang dapat memberikan solusi yang tepat untuk dapat menangani permasalahan tersebut. Aplikasi yang dikembangkan ini bertujuan untuk membantu memberikan informasi yang jelas bagi pasien atau masyarakat umum dan bagi tenaga medis diharapkan dapat membantu dalam penanganannya memberikan solusi yang tepat, dengan hanya memperhatikan gejalagejala yang dialami. Subjek dalam penelitian ini adalah sistem pakar untuk mendiagnosa penyakit saluran pencernaan. Hasil penelitian ini adalah sistem pakar untuk mendiagnosa penyakit saluran pencernaan sebanyak 19 jenis penyakit dan menggunakan metode Dempster Shafer untuk mendapatkan nilai kepastian berupa persentase pada hasil diagnosa penyakitnya.

\section{LANDASAN TEORI Sistem Pakar}

Sistem pakar (Expert System) adalah sistem yang berusaha mengadopsi pengetahuan manusia ke komputer agar komputer dapat menyelesaikan masalah seperti yang biasa dilakukan oleh para ahli. Sistem pakar yang baik dirancang agar dapat menyelesaikan suatu permasalahan tertentu dengan meniru kerja dari para ahli. Dengan sistem pakar ini, orang awa m pun dapat menyelesaikan masalah yang cukup rumit yang sebenarnya hanya dapat diselesaikan dengan bantuan para ahli. Bagi para ahli, sistem pakar ini juga akan membantu aktivitasnya sebagai asisten yang sangat berpengalaman.

Pada dasarnya sistem pakar diterapkan untuk mendukung aktivitas pemecahan masalah. Beberapa aktivitas pemecahan yang dimaksud seperti pembuatan keputusan (decision making ), pemanduan pengetahuan (knowledge fusing), pembuatan desain(designing), perencanaan (planning), prakiraan (forescasing), pengaturan (regulating), pengendalian (controlling), diagnosa (diagnosing), perumusan (prescribing), penjelasan (explaning), pemberian nasihat (advising) dan pelatihan (tutoring) (Arhami, 2005). Setiap user menyampaikan fakta atau informasi untuk sistem pakar kemudian menerima saran dari pakar atau jawaban ahlinya. Dalam sistem pakar terdiri dari 2 komponen utama, yaitu knowledge - base dan mesin inferensi yang menggambarkan kesimpulan. kesimpulan tersebut merupakan respons dari sistem pakar atas permintaan user.

Metode Dempster-Shafer 
Teori Dempster-Shafer pertama kali diperkenalkan oleh oleh Arthur P. Dempster and Glenn Shafer, yang melakukan percobaan ketidakpastian dengan range probabilities daripada sebagai probabilitas tunggal. Kemudian pada tahun 1976 Shafer mempublikasikan teori Dempster pada buku yang berjudul Mathematichal Theory of Evident. Teori Dempster-Shafer merupakan teori matematika dari evidence. Teori tersebut dapat memberikan sebuah cara untuk menggabungkan evidence dari beberapa sumber dan mendatangkan atau memberikan tingkat kepercayaan (direpresentasikan melalui fungsi kepercayaan) dimana mengambil dari seluruh evidence yang tersedia (Kurniawati, dkk, 2014). Secara umum Teori DempsterShafer ditulis dalam suatu interval: [Belief, Plausibility] Belief (Bel) adalah ukuran kekuatan evidence dalam mendukung suatu himpunan proposisi. Jika bernilai 0 maka mengindikasikan bahwa tidak ada evidence, dan jika $\mathrm{m}$ bernilai 1 menunjukkan adanya kepastian. Plausibility (Pl) dinotasikan sebagai:

$$
P 1(s)=1-\operatorname{Bel}(\dashv s)
$$

Plausibility juga bernilai 0 sampai 1. Jika kita yakin akan $-\mathrm{s}$, maka dapat dikatakan bahwa $\operatorname{Bel}(\dashv s)$, dan $P 1(\dashv s)=0$.

Plausability akan mengurangi tingkat kepercayaan dari evidence. Pada teori Dempster-Shafer kita mengenal adanya frame of discernment yang dinotasikan dengan $\theta$ dan mass function yang dinotasikan dengan $\mathrm{m}$. fungsi kombinasi $\mathrm{m} 1$ dan $\mathrm{m} 2$ sebagai $\mathrm{m} 3$ dibentuk dengan

persamaan : $M 3(Z)=\frac{\sum_{X \cap Y=Z} m 1(X) \cdot m 2(Y)}{1-K}$

Dimana $K=\sum_{X \cap Y=\varnothing} \quad m 1(X) \cdot m 2(Y)$

Dengan :

M1 (X) adalah mass function dari evidence $\mathrm{X}$
M2 (Y) adalah mass function dari evidence $\mathrm{Y}$

M3(Z)adalah mass function dari evidence $\mathrm{Z}$

$\mathrm{K}$ adalah jumlah conflict evidence

\section{METODE PENILITIAN}

Data yang digunakan dalam penelitian ini diperoleh dari Puskesmas Rawat Inap Ome Kota Tidore Kepulauan. objek penelitian berupa data status gizi buruk pada anak usia dari 0 - 10 tahun.

\section{Alat dan Bahan}

Peralatan bantu yang digunakan pada penelitian ini adalah :

1. Computer dengan spesifikasi : processor intel (R) Celeron(R) 1.50GHz, RAM 2,00GB, Harddisk 500GB

2. Bahasa pemrograman yang digunakan adalah Editor Web Dreamweaver 8, xammp, data base MySql

\section{ANALISIS DAN PERANCANGAN Flowchart system}

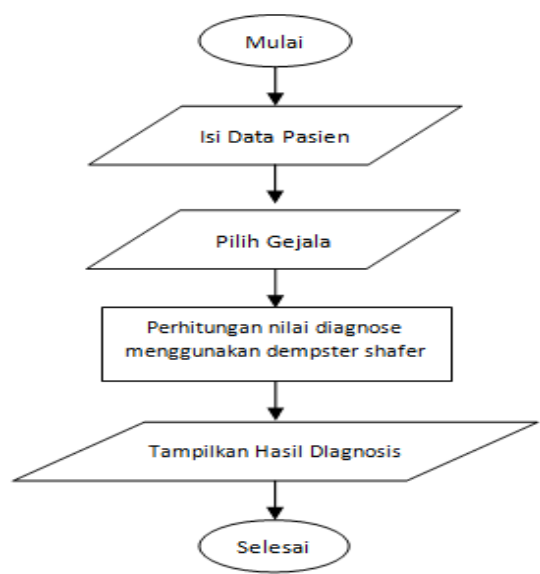

Gambar 1. Flowchart sistem aplikasi

Pada Gambar 1, Tahap awal adalah pasien harus mengisi data pasien terlebih dahulu. Langkah kedua, pasien akan memilih data gejala yang dialaminya. Langkah ketiga sistem akan menghitung rumus dengan menggunakan metode Dempster-shafer. Kemudian output 
memberikan hasil diagnose penyakit yang diderita oleh pasien.

\section{IMPLEMENTASI DAN PEMBAHASAN Halaman Pengunjung}

Pada tampilan gambar di bawah ini adalah halaman utama pengunjung pada program sistem pakar untuk mendiagnosa jenis gizi buruk pada anak. Dengan isi konten terdapat gambar anak mengalami gizi buruk.

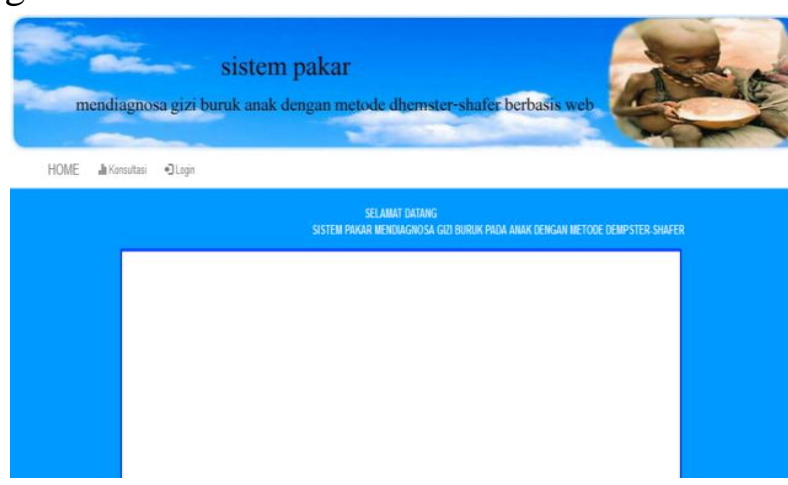

Gambar 2. Halman Pengunjung

\section{Halaman Data Konsultasi}

Pada Gambar. 3 pengunjung diminta untuk mendaftarkan diri sebelum melakukan konsultasi, pengunjung diharuskan mengisi datanya dengan jelas dan benar.

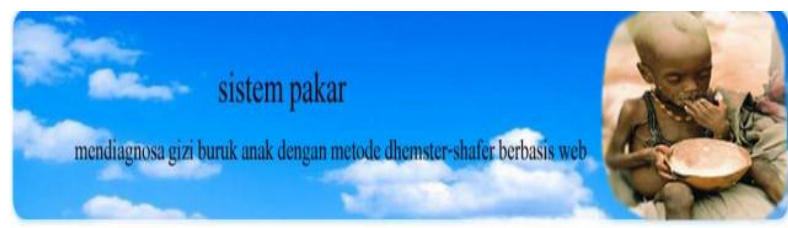

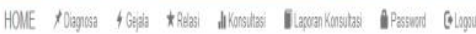

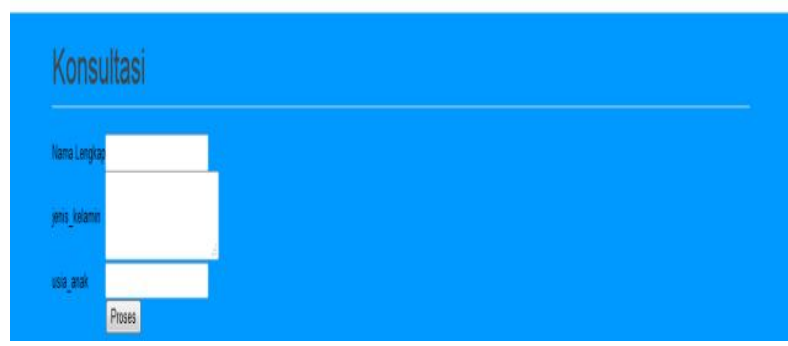

Gambar 3. Data Konsultasi

\section{Halaman Konsultasi}

Gambar 4. Pengunjung diminta untuk memilih gejala penyakit dialami, dengan memberi tanda centang pada ciri-ciri gejala penyakit yang di tampilkan oleh pakar. Hal ini bertujuan agar pakar dapat menentukan jenis penyakit gizi buruk yang dialami oleh pengunjung.

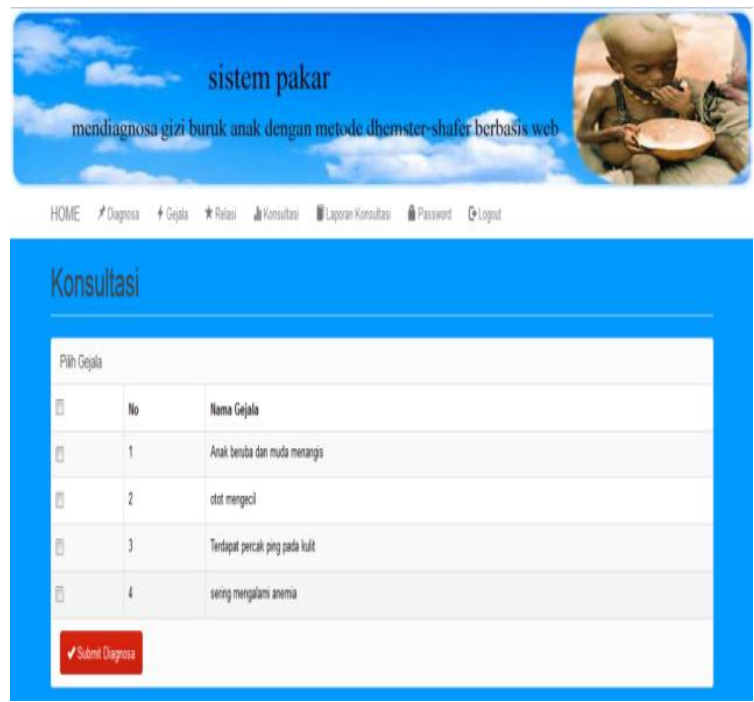

Gambar 4. Halaman Konsultasi

\section{Halaman Hasil Konsultasi}

Halaman hasil konsultasi merupakan form yang berfungsi untuk menampilkan informasi hasil konsultasi yang dilakukan oleh user setelah melakukan konsultasi, pengunjung dapat mengetahui jenis penyakit gizi buruk anak yang dialami, serta pengunjung dapat melihat solusi penyakit gizi buruk anak

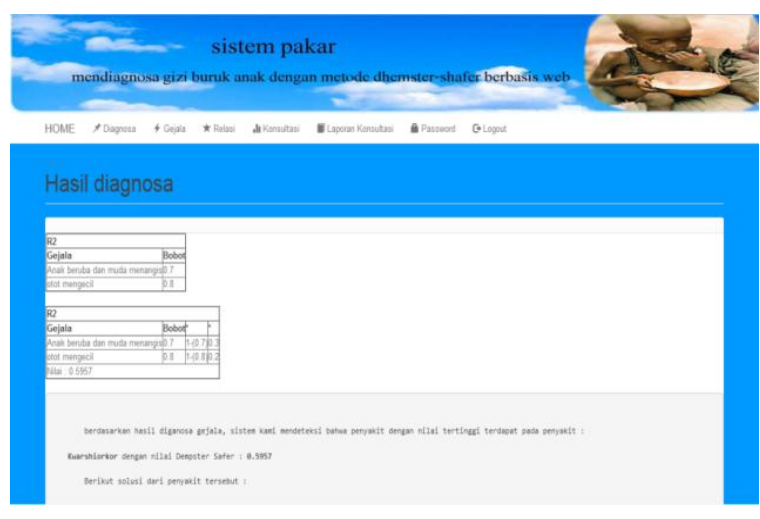

Gambar 5. Hasil Konsultasi

\section{Halaman Login Administrator}

Pada gambar menu login berikut, seorang admin dituntut untuk melakukan 
regestrasi hak akses agar dapat mengelola isi dari halaman sistem pakar admin.

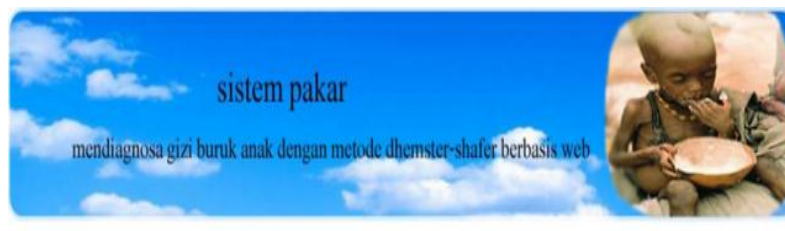

HOME WIMndasi Dlun

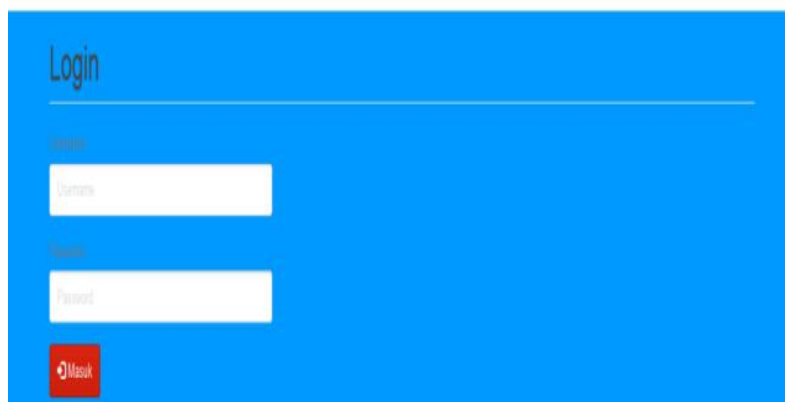

Gambar 6. Login administrator

\section{Halaman Daftar Diagnosa}

Pada menu daftar diagnosa ini akan menampilkan daftar data diagnosa atau jenis gejala penyakit gizi buruk

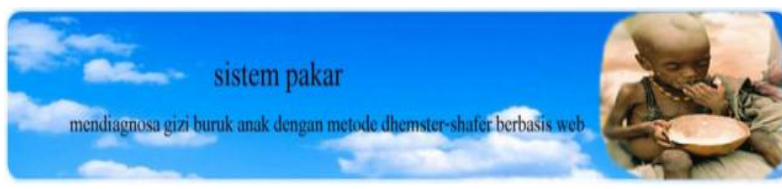

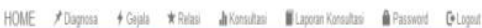

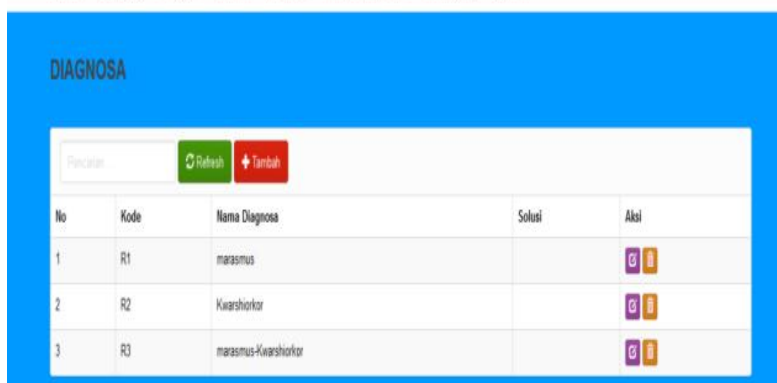

Gambar 7. Daftar Diagnosa

\section{Halaman Tambah diagnose}

Pada menu tambah diagnosa ini akan menampilkan suatu form untuk menginput data diagnosa kedalam sistem pakar

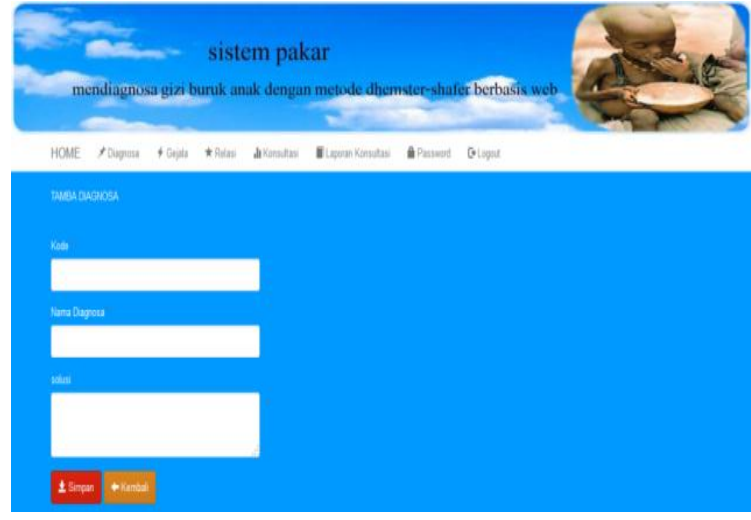

Gambar 8. Tambah Diagnosa

\section{Halaman Data Gejala}

Pada menu daftar Gejala ini akan menampilkan daftar data Gejala

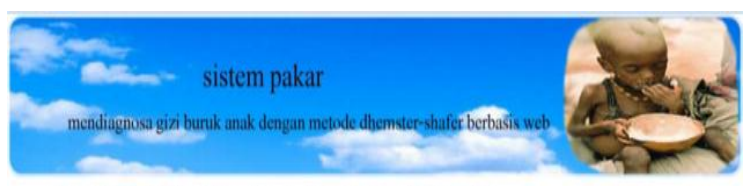

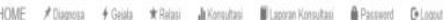

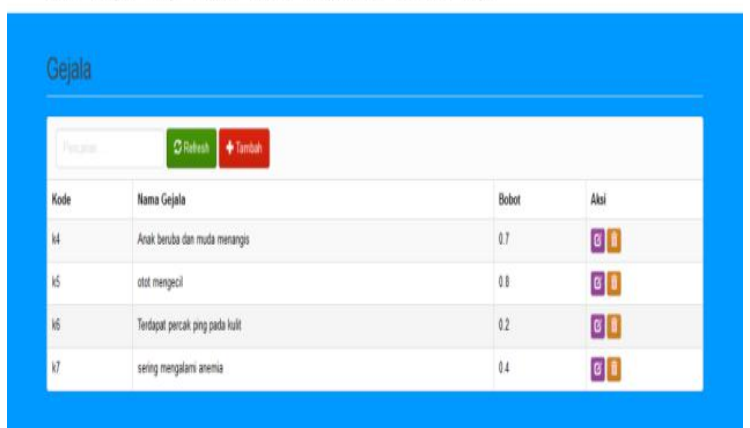

Gambar 9. Data Gejala

\section{Halaman daftar relasi}

Pada menu daftar Relasi ini akan menampilkan daftar penyelarasan Data Diagnosa dengan Data Gejala

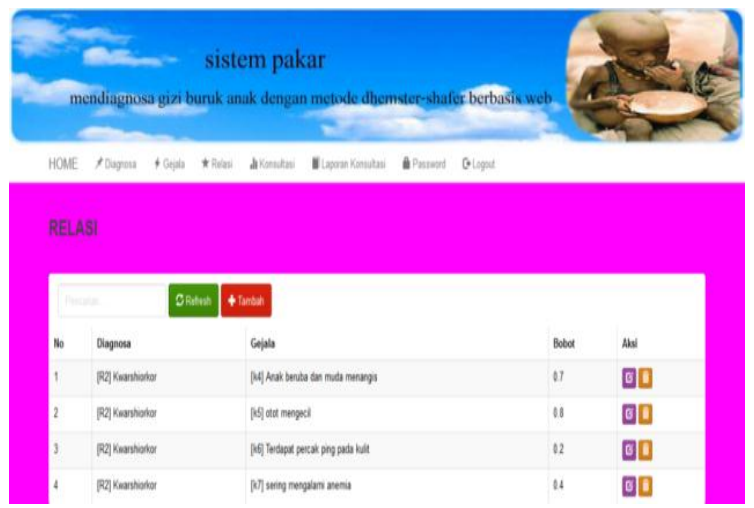

Gambar 10. Daftar Relasi 


\section{Halaman laporan konsultasi}

Pada halaman atau menu data laporan data konsultasi pengunjung ini terdapat data atau identitas pengunjung yang diinput oleh pengunjung, berupa nama, jenis kelamin, usia anak, mengidap penyakit, tanggal konsultasi.

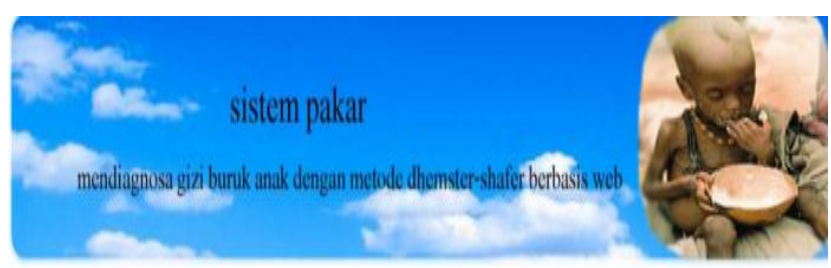

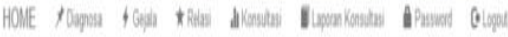

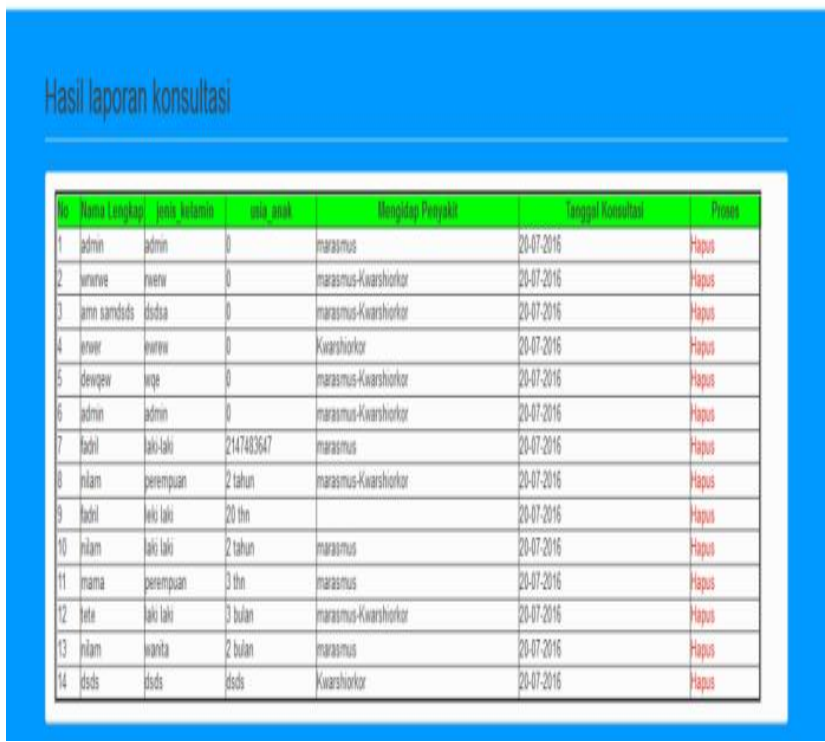

Gambar 11. Halaman Laporan Konsultasi

\section{KESIMPULAN}

Berdasarkan pembahasan yang telah diuaraikan pada bab-bab sebelumnya maka diambil beberapa kesimpulan sebagai berikut.

1. aplikasi Sistem pakar deteksi status gizi buruk pada anak ini mampu mengambil kesimpulan diagnosa status jenis gizi burukpada anak, menggunakan masukan gejala fakta dari pengguna.

2. Sistem pakar deteksi status gizi anak ini mampu menidentifikasi dan pengambilan kesimpulan status penyakit gizi buruk apa yang diderita pasien dengan perhitungan menggunakan metode Dempster-shafer dan memberiksn solusi penanganannya

\section{Saran}

Sistem pakar ini dapat dikembangkan dengan menggunakan metode yang lain, agar memperoleh hasil penilaian yang lebih optimal. Data mengenai gejal-gejala gizi buruk dapat ditambah lebih banyak agar pengguna lebih tahu secara detail

\section{DAFTAR PUSTAKA}

Kementrian Kesehatan Republik Indonesia. 2013. Profil Kesehatan Indonesia.

Zainollah Effendi., L, Rakhmatillah. Sistem pakar diagnose penyakit pada anak menggunakan metode Dempster-Shafer. JURNAL LINK VOL 23 No.2 2015.

Erna Kusumawati., Setiyowati, Rahardjo. 2012. Pengaruh Pelayanan Kesehatan Terhadap Gizi Buruk Anak Usia 6-24 Bulan. Jurnal Kesmas.Vol.6,No.4.

Grace, Apriliany, Presilia Kurmasela., Gisela, Nina, Sevani. Aplikasi DIagnosa Gizi Buruk Pada Balita Menggunakan Metode Pembobotan (Studi Kasus : Kecamatan NUSANIWE, Kota AMBON). Vol.6 No.1.Maret

Arhami. 2005. Konsep Dasar Sistem Pakar. Andi. Yogyakarta:

Kurniawati, Dewi, Pratama. 2014. Implementasi Metode Dempster Shafer Pada Sistem Pakar Untuk Diagnosa Jenis-Jenis Penyakit Diabetes Melitus.

Rizky Ambarita, Sistem Pakar Diagnosa Kerusakan Mainboard Komputer, IJIS Indonesian Journal On Information System, Vol 2 No 1 April 2017, ISSN 2548-6438

Yasidah Nur Istiqomah, Abdul Fadlil, Sistem Pakar untuk Mendoagnosa Penyakit Saluran Pencernaan Menggunakan Metode Dempster Shafer, Jurnal Sarjana Teknik Informatika, Vol 1 No 1 2013, e-ISSN: 2338-5197 